Original Research Paper

\title{
Pengaruh Metode Isolasi a-mangostin dari Kulit Buah Manggis (Garcinia mangostana L.) terhadap Rendemen $\alpha$-mangostin
}

\author{
Sri Idawati ${ }^{1 *}$, Aliefman Hakim², Yayuk Andayani ${ }^{2}$ \\ ${ }^{1}$ Politeknik Medica farma Husada Mataram, Indonesia; \\ ${ }^{2}$ Program Studi Magister Pendidikan IPA Pascasarjana Universitas Mataram, Indonesia
}

\section{Article history}

Received: October $16^{\text {th }} 2018$

Revised: January $18^{\text {th }} 2019$

Accepted: March $14^{\text {th }} 2019$

*Sri Idawati: Politeknik

Medica farma Husada

Mataram, Indonesia;

Email:

sriidawatiqk@gmail.com

\begin{abstract}
The purpose of this research is to know the effect of the isolation method of the yield of $\alpha$-mangostin resulting from mangosteen rind. Mangosteen (Garcinia mangostana L.) is the source of xanthone secondary metabolites. Derivatives xanthone which is the main bioactive compound and becomes a major compound in the mangosteen plant, namely $\alpha$-mangostin. This main compound has been isolated from ethanol extract on mangosteen rind using different extraction methods namely maceration and soxhletation. Purification was done by the recrystallization method with solvent ethanol: aquades (1:1). The Maceration extraction method produce the yields of extract and the yields of pure compounds ( $\alpha$-mangostin) is higher than that of soxhletation. The Maceration extraction method produces yields of extract 30,12\% and yields of $\alpha$-mangostin $4,27 \%$ while the soxhletation extraction method produce the yields of extract $26,34 \%$ and the yields of $\alpha$-mangostin 2,13\%. This yellow powder isolate has a melting point of $179,7{ }^{\circ} \mathrm{C}$. Purification is monitored by thin layer chromatography (TLC) and structural elucidation is carried out using FT-IR spectroscopy data.
\end{abstract}

Key Words: Isolation, $\alpha$-mangostin, Garcinia mangostana

Abstrak: Tanaman manggis (Garcinia mangostana L.) merupakan sumber senyawa metabolit sekunder golongan santon. Derivat santon yang merupakan senyawa bioaktif utama dan menjadi mayor compound dalam tanaman manggis yaitu $\alpha$-mangostin. Senyawa utama ini telah berhasil diisolasi dari ekstrak etanol pada kulit buah manggis menggunakan 2 metode ekstraksi berbeda yaitu maserasi dan sokletasi. Pemurnian dilakukan dengan metode rekristalisasi dengan pelarut etanol:aquades (1:1). Metode ekstraksi maserasi menghasilkan rendemen ekstrak dan rendemen senyawa murninya ( $\alpha$-mangostin) lebih tinggi dibandingkan metode ekstraksi sokletasi. Metode ekstraksi maserasi menghasilkan rendemen ekstrak 30,12\% dan rendemen $\alpha$-mangostin 4,27\% sedangkan metode ekstraksi sokletasi menghasilkan rendemen ekstrak 26,34\% dan rendemen $\alpha$-mangostin $2,13 \%$. Isolat berupa serbuk kuning ini memiliki titik leleh $179,7^{\circ} \mathrm{C}$. Pemurnian dimonitoring dengan kromatografi lapis tipis (KLT) dan elusidasi struktur dilakukan dengan menggunakan data spektroskopi FT-IR.

Kata Kunci: Isolasi, $\alpha$-mangostin, Garcinia mangostana

\section{Pendahuluan}

Isolasi adalah suatu cara untuk mengambil satu senyawa aktif yang terdapat di dalam tanaman untuk mengetahui senyawa yang berkhasiat dalam tanaman tersebut. Isolasi metabolit sekunder dari suatu tumbuhan terdiri atas tahapan penyiapan simplisia/sampel, ekstraksi, fraksinasi, pemurnian, dan karakterisasi senyawa isolat. Isolasi metabolit sekunder dari berbagai bagian tumbuhan memiliki tingkat kesulitan yang berbeda-beda. Beberapa faktor yang mempengaruhi tingkat kesulitan tersebut adalah ada tidaknya metabolit sekunder mayor dalam sampel dan jauh dekatnya Rf antara 
berbagai komponen dalam sampel. Faktor-faktor inilah yang harus dipertimbangkan sebelum merancang sebuah prosedur isolasi (Hakim, 2016).

Tumbuhan dapat menghasilkan senyawa metabolit primer dan metabolit sekunder. Protein, lemak, dan polisakarida merupakan penyusun utama dari organisme sehingga disebut sebagai metabolit primer. Metabolit sekunder berperan untuk kelangsungan hidup suatu spesies dalam perjuangan menghadapi spesies lain atau faktor lingkungan lainnya. Zat kimia yang dihasilkan dapat berfungsi sebagai pertahanan, penarik seks dan feromon (Manitto, 1992). Senyawa - senyawa yang termasuk metabolit sekunder diantaranya adalah terpenoid, polifenol, steroid, flavonoid, ksanton, benzofenon, kumarin, tanin dan alkaloid (Hakim, 2016).

Heyne (1987) dalam (Miryanti, dkk., 2011), mengatakan bahwa secara umum kulit buah manggis mengandung senyawa metabolit sekunder yaitu ksanton, flavonoid, dan tanin. Kandungan utamanya adalah golongan ksanton. Metabolit sekunder golongan ksanton ini merupakan substansi kimia alami yang tergolong senyawa polifenol. Ksanton terdiri dari cincin aromatis trisiklik yang disubstitusi dengan berbagai gugus fenolik, metoksi dan isoprene (Obolskiy, dkk., 2009). Senyawa aktif utama dan merupakan senyawa mayor dari derivat ksanton yang terdapat dalam kulit buah manggis adalah $\alpha$-mangostin.

$\alpha$-mangostin memiliki berbagai bioaktivitas yaitu antibakteri (Koh dkk, 2013), antioksidan (Sanchez-Perez dkk, 2010; Kumar dkk, 2017), antiinflamasi dan alergi (Cui dkk, 2010; Chae dkk, 2012; Kumar dkk, 2017), antifungi (Suksamrarn dkk, 2003), antiparasit (Larson dkk, 2010; Keiser dkk, 2012), antiobesitas (Quan dkk, 2012), antidiabetes (Kumar dkk, 2017) serta aktivitas antikanker pada kanker hepatoseluler, dan kanker payudara (Moongkarndi, 2004).

Senyawa $\alpha$-mangostin berupa zat berwarna kuning, tidak larut dalam air, larut dalam metanol, etanol, eter, aseton, etil asetat, dan kloroform (Syamsudin, dkk., 2008). $\alpha$-mangostin memiliki rumus molekul $\mathrm{C}_{24} \mathrm{H}_{26} \mathrm{O}_{6}$ dengan berat molekul $410.4596 \mathrm{~g} / \mathrm{mol}$. Nama IUPAC $\alpha$-mangostin adalah 1,3,6-trihidroksi-7-metoksi-2,8-bis(3-metil2 butenil)-9H-xantin-9-on) (Putri, 2015).

$\alpha$-mangostin memiliki titik leleh/lebur 178-

$180{ }^{0} \mathrm{C}$ (Shankaranarayan dkk, 1979). pada pengukuran dengan UV panjang gelombang $(\lambda)$ maksimum yang diperoleh adalah 215, 243, 317 nm, sedangkan pada IR diperoleh bilangan gelombang ( $\mathrm{V}_{\text {maks }}$ ) sebesar 3422, 2922, 1642, 1610 nm (Ee dkk., 2008).<smiles>COc1c(O)cc2oc3cc(O)c(CC=C(C)C)c(O)c3c(=O)c2c1CC=C(C)C</smiles>

Gambar 1. Struktur kimia $\alpha$-mangostin

\section{Metode}

\section{Bahan dan Alat}

Bahan yang digunakan dalam penelitian ini adalah simplisia kulit buah manggis, pelarut etanol $96 \%$, aquades, kertas saring, plat silica untuk KLT. Peralatan yang digunakan adalah blender, ayakan, toples, penyaring, batang pengaduk, peralatan soklet, gelas ukur, tabung erlen meyer, rotary evaporator, lampu ultraviolet (UV) dengan $\lambda 254$ dan $366 \mathrm{~nm}$, spektrofotometer IR.

\section{Metode Isolasi $\alpha$-mangostin Pembuatan Simplisia}

Kulit buah manggis matang dan segar sebanyak $1 \mathrm{~kg}$ dibersihkan, kemudian dipotongpotong tipis dan dikeringanginkan selama 8 hari hingga menjadi simplisia (bahan kering). Simplisia kulit buah manggis tersebut diblender dan kemudian diayak. Serbuk kering disimpan dalam wadah kedap udara dan terlindung dari cahaya.

\section{Ekstraksi Metode Maserasi}

Seratus gram serbuk kering kulit buah manggis dimaserasi dengan $500 \mathrm{ml}$ etanol $96 \%$ pada suhu kamar selama 24 jam. Maserat disaring dan diremaserasi dengan $200 \mathrm{ml}$ etanol $96 \%$ pada suhu kamar selama 24 jam. Ekstrak total yang didapatkan dievaporasi pada suhu $70^{\circ} \mathrm{C}$ dengan kecepatan 70 rpm hingga diperoleh ekstrak kental.

\section{Ekstraksi Metode Sokletasi}

Seratus gram serbuk kering kulit buah manggis dimasukkan ke dalam tabung soklet dengan pelarut etanol $96 \% 500 \mathrm{ml}$ pada suhu $60{ }^{\circ} \mathrm{C}$ selama 60 menit. Hasil soklet diambil, kemudian dilakukan sokletasi ulang dengan menggunakan pelarut etanol $96 \% 200 \mathrm{ml}$. Ekstrak total yang didapatkan dievaporasi pada suhu $60^{\circ} \mathrm{C}$ dengan kecepatan $70 \mathrm{rpm}$ hingga diperoleh ekstrak kental. 


\section{Pemurnian Ekstrak Kulit Buah Manggis}

Ekstrak kulit buah manggis yang diperoleh dimurnikan menggunakan metode rekristalisasi. Ekstrak dilarutkan dengan etanol kemudian ditambahkan aquades (perbandingan etanol:aquades adalah 1:1), dinginkan dalam lemari pendingin pada suhu $4^{0} \mathrm{C}$ selama 24 jam. Antara Kristal dan cairan dipisahkan dengan cara disaring menggunakan kertas saring. Isolat dimonitoring dengan kromatografi lapis tipis (KLT), dilakukan uji titik leleh dan kemudian dilanjutkan dengan identifikasi spektrofotometri FT-IR.

\section{Hasil dan Pembahasan}

Isolasi $\alpha$-mangostin dari kulit manggis ini dilakukan melalui proses ekstraksi, purifikasi/pemurnian dan elusidasi struktur. Kulit buah manggis segar dirajang hingga menjadi potongan-potongan kecil dan dikeringkan untuk menghilangkan kadar air dalam dalam sampel tersebut. Sampel kering diblender hingga berbentuk serbuk untuk memperluas permukaan dari sampel. Serbuk kulit buah manggis tersebut selanjutnya di ekstraksi secara maserasi dan sokletasi.

Metode ekstraksi maserasi yaitu proses pengekstraksian atau penyarian simplisia dengan menggunakan pelarut dengan beberapa kali pengocokan atau pengadukan pada temperatur ruang (suhu kamar) (Andayani, 2015). Sokletasi adalah ekstraksi menggunakan pelarut yang selalu baru umumnya dilakukan dengan alat khusus sehingga terjadi ekstraksi kontinyu dengan jumlah pelarut relatif konstan dengan adanya pendinginan balik. Metode ini dapat mengekstraksi sampel yang tahan terhadap pemanasan secara langsung (Hakim, 2016). Perbedaan ekstraksi secara maserasi dan sokletasi adalah perlakuan terhadap bahan baku. Pada metode maserasi, bahan baku direndam dengan pelarut dalam wadah toples pada suhu kamar dengan beberapa kali pengadukan sedangkan pada metode sokletasi, bahan baku dimasukkan ke dalam sebuah tabung soklet dan pelarut dalam labu ekstraksi, kontak antara pelarut dengan bahan baku dilakukan dengan pemanasan. Pada proses maserasi terjadi perbedaan konsentrasi zat aktif di dalam dan di luar sel menyebabkan terjadinya difusi zat aktif yang ada dalam sel akan keluar sel (Mutmainnah, dkk., 2017).

Pelarut pengekstraksi menggunakan etanol yang merupakan pelarut universal yang dapat melarutkan hampir semua zat aktif baik yang bersifat non polar, semi polar maupun polar. Keuntungan lain etanol digunakan sebagai pelarut pengekstraksi adalah sifatnya yang tidak toksik, mudah didapat dan harganya terjangkau. Etanol juga dapat mengendapkan protein serta mampu menghambat kerja enzim sehingga dapat terhindar dari proses hidrolisis dan oksidasi.

Rendemen ekstrak etanol kulit buah manggis yang diperoleh dari proses maserasi adalah 30,12\% sedangkan dari proses sokletasi 26,34\%. Hal ini memperlihatkan bahwa dengan proses ekstraksi yang lebih mudah dan sederhana (maserasi) mampu menghasilkan ekstrak yang lebih banyak. Ekstrak yang diperoleh tersebut kemudian dimurnikan dengan cara rekristalisasi menggunakan pelarut etanol:aquades (1:1). Pemilihan pelarut tersebut didasarkan pada prinsip rekristalisasi yaitu melarutkan senyawa yang akan dimurnikan kemudian ditambahkan pelarut yang tidak dapat melarutkan senyawa tersebut. Awalnya sampel dilarutkan dengan etanol dan terbentuk larutan bening, kemudian larutan tersebut ditambahkan aquades (tidak melarutkan senyawa) dan selanjutnya didinginkan pada suhu $4^{\circ} \mathrm{C}$ untuk mempercepat dan memperbanyak terbentuknya kristal, lalu kristal dan cairan dipisahkan melalui penyaringan.

Kristal yang terbentuk dimonitoring dengan kromatografi lapis tipis (KLT) menggunakan eluen kloroform. Setelah terbentuk satu spot/bercak pada KLT dengan nilai Rf 0,3, kemudian kristal dikeringkan dan ditimbang. Rendemen $\alpha$-mangostin yang dihasilkan dari ekstrak dengan metode maserasi adalah 4,27\% sedangkan dengan metode sokletasi 2,13\%. Metode ekstraksi maserasi menghasilkan rendemen ekstrak dan rendemen $\alpha$ mangostin yang lebih tinggi dibandingkan dengan metode sokletasi.Hal ini terjadi karena proses sokletasi membutuhkan pemanasan agar terjadi kontak antara pelarut dengan bahan baku serta waktu yang lebih lama. Pada suhu $60^{\circ} \mathrm{C}$ dan waktu 60 menit proses sokletasi belum optimum karena titik didih etanol adalah $78,3^{\circ} \mathrm{C}$, sehingga proses penguapan pelarut masih berlangsung sebagian. Pada proses maserasi, pelarut dan bahan baku sudah terjadi kontak pada saat pencampuran dan adanya proses pengadukan mampu mengoptimalkan kontak antara pelarut dan bahan baku.

Senyawa isolat berupa serbuk kuning tersebut selanjutnya diuji titik lelehnya menggunakan alat pengukur titik leleh (A. KRUSS OPTRONIC Germany) dan dihasilkan nilai titik lelehnya adalah $179,7^{\circ} \mathrm{C}$. Hal ini sesuai dengan yang dilaporkan oleh Shankaranarayan dkk. (1979) bahwa titik leleh $\alpha$-mangostin adalah $178-180{ }^{\circ} \mathrm{C}$. Selanjutnya diidentifikasi menggunakan data 
spektroskopi FT-IR (Infra Red). Pada spektrum IR menunjukkan serapan-serapan yang khas untuk beberapa gugus fungsi, diantaranya adalah pada bilangan gelombang $\left(\mathrm{V}_{\text {maks }}\right) \quad 3423 \mathrm{~cm}^{-1}$ menunjukkan adanya hidroksil bebas, sedangkan serapan pada bilangan gelombang $\left(\mathrm{V}_{\text {maks }}\right) 2990 \mathrm{~cm}^{-}$ 1, $2962 \mathrm{~cm}^{-1}, 2923 \mathrm{~cm}^{-1}$ dan $2854 \mathrm{~cm}^{-1}$ menunjukkan adanya gugus $\mathrm{C}-\mathrm{H}$ alifatik. Serapan dengan bilangan gelombang $\left(\mathrm{V}_{\text {maks }}\right) 1643 \mathrm{~cm}^{-1}$ menunjukkan adanya satu karbonil yang terkhelat oleh gugus hidroksi, sedangkan serapan pada bilangan gelombang ( $\left.\mathrm{V}_{\text {maks }}\right) 1612 \mathrm{~cm}^{-1}$ dan 1584 $\mathrm{cm}^{-1}$ menunjukkan kekhasan $-\mathrm{C}=\mathrm{C}$ - aril $\mathrm{sp}^{2}$ pada sistem aromatik dan serapan pada bilangan gelombang ( $\left.\mathrm{V}_{\text {maks }}\right) 1280 \mathrm{~cm}^{-1}$ menunjukkan adanya satu gugus $-\mathrm{C}-\mathrm{O}$ eter. Berikut ditampilkan spektrum hasil uji spektroskopi FT-IR.

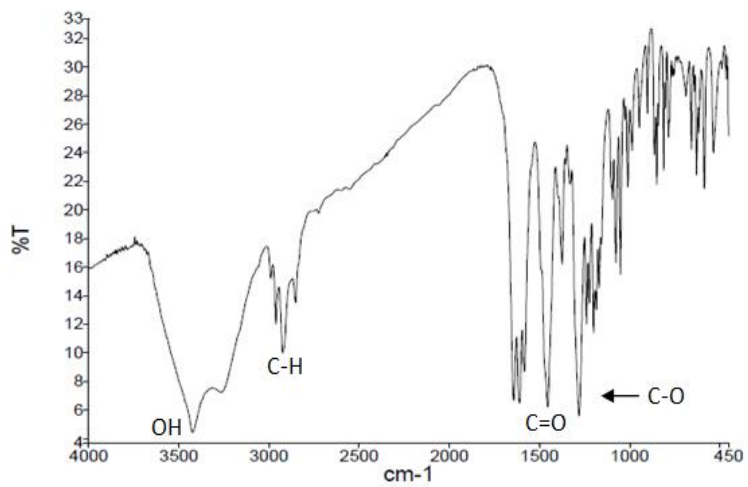

Gambar 2. Spektrum IR $\alpha$-Mangostin

Berdasarkan analisa data FT-IR dapat diketahui bahwa senyawa isolat memiliki gugus karbonil terkhelat, gugus hidroksil bebas, gugus C$\mathrm{H}$ alifatik dan sistem aromatik yang sesuai dengan kerangka ksanton dan senyawa tersebut memiliki kesamaan struktur dengan senyawa $\alpha$-mangostin (Ahmat, dkk., 2010).

\section{Kesimpulan}

Isolasi $\alpha$-mangostin dari kulit buah manggis yang diekstraksi menggunakan metode maserasi menghasilkan rendemen ekstrak dan rendemen $\alpha$ mangostin $(30,12 \%$ dan $4,27 \%)$ lebih tinggi dibandingkan dengan metode sokletasi $(26,34 \%$ dan 2,13\%). Pemurnian secara rekristalisasi menghasilkan isolat berupa serbuk berwarna kuning dengan titik leleh $179,7^{\circ} \mathrm{C}$ dan elusidasi struktur menggunakan data spektroskopi FT-IR menunjukkan bahwa senyawa isolat adalah $\alpha$ mangostin.

\section{Daftar Pustaka}

Ahmat, N., Azmin, N.F.N., Ab Ghani, N., Aris, S.R.S. 2010. Bioactive Xanthones from the Pericarp of Garcinia mangostana. MiddleEast Journal of Scientific Research: 6(2), Malaysia, 123-127.

Andayani, R., Novita, R dan Verawati. 2015. Pengaruh Metode Ekstraksi terhadap Kadar Xanton Total dalam Ekstrak Kulit Buah Manggis Matang (Garcinia mangostana L.). Prosiding Seminar Nasional \& Workshop "Perkembangan Terkini Sains Farmasi \& Klinik 5" 6-7 November 2015, Universitas Andalas, Padang.

Chae, H.-S., Oh, S.-R., Lee, H.-K., Joo, S.H., Chin, Y.-W., 2012. Mangosteen xanthones, $\alpha$ and $\gamma$-mangostins, inhibit allergic mediators in bone marrow-derived mast cell. Food Chem. 134:397-400.

Ee., GCL., Daud, S., Izzaddin, SA dan Rahmare, M. 2008. Garcinia mangostana: a source of potential anti-cancer lead compounds against CEM-SS cell line. J Asian Nat Prod Res 10(5):475-479.

Hakim, A. 2016. Meningkatkan Kualitas Pembelajaran Kimia Bahan Alam Melalui Praktikum. Mataram: Arga Puji Press.

Keiser, J., Vargas, M., Winter, R., 2012. Anthelminthic properties of mangostin and mangostin diacetate. Parasitol. Int. 61:369371.

Koh, J-J., Qiu, S., Zou, H., Lakshminarayanan, R., Li, J., Zhou, X., Tang, C., Saraswathi, P., Verma, C., Tan, D.T.H., Tan, A.L., Liu, S., Beuerman, R,W. 2013. Rapid Bactericidal Action of Alpha-Mangostin against MRSA as An Outcome of Membrane Targeting. Biohimica et Biophysica Acta.1828:834844.

Kumar, Pradeep S.V., Puranik, B and Nandini, B.N. 2017. Evaluation of Alpha-Mangostin, Isolated and Purified from the Crude Extract of Garcinia mangostana for the Anti-Diabetic, Anti-inflamtory and Antioxidant Avtivity. Human Journals. 8(2):76-95.

Larson, R.T., Lorch, J.M., Pridgeon, J.W., Becnel, J.J., Clark, G.G., Lan, Q., 2010. The biological activity of alpha-mangostin, a larvicidal botanic mosquito sterol carrier protein-2 inhibitor. J. Med. Entomol. 47:249-257. 
Manitto, P. 1992. Biosintesis Produk Alami. Penerjemah Koensoenardiyah, IKIP Surabaya.

Miryanti, A., Sapei, L., Budiono, K., Indra, S. 2011. Ekstraksi Antioksidan Dari Kulit Buah Manggis (Garcinia mangostana L.). Lembaga Penelitian dan Pengabdian Kepada Masyarakat Universitas Katolik Parahyangan Bandung.

Moongkarndi, P., Kosem, N., Kaslungka, S., Luanratana, O., Pongpan, N., Neungton, N. 2004. Antiproliferation, Antioxidant and Induction Of Ap(optosis By Garcinia mangostana mangosteen) on SKBR3 Human Breast Cancer Cell Line. $J$ Ethnopharmacol. 90(1):66-161.

Mutmainnah, P.A., Hakim, A., Savalas, L.R.T. 2017. Identifikasi Senyawa Turunan Hasil Fraksinasi Kayu Akar Artocarpus Odoratissimus. Jurnal Penelitian Pendidikan IPA (JPPIPA). 3(2), Juli 2017.

Obolskiy, D., P, Ivo., S, Nisarat., H, Michael. 2009. Garcinia mangostana L: A phytochemical and Pharmacological Review. Phytoter. Res. 23 : 1047-1065.

Putri, I.P. 2015. Effectivity of Xanthone Of Mangosteen (Garcinia mangostana L.) Rind As Anticancer. J Majority. 4(1):33-38.

Quan, X., Wang, Y., Liang, Y., Tian, W., Ma, Q., Jiang, H., Zhao, Y., 2012. a -Mangostin induces apoptosis and suppresses differentiation of 3T3-L1 cells via inhibiting fatty acid synthase. PLoS One 7:33376-33379.

Sanchez-Perez, Y., Morales-Barcenas, R., GarciaCuellar, C.M., Lopez-Marure, R., Calderon-Oliver, M., Pedraza-Chaverri, J., Chirino, Y.I., 2010. The $\alpha$-mangostin prevention on cisplatin-induced apoptotic death in LLC-PK1 cells is associated to an inhibition of ROS production and p53 induction. Chem. Biol. Interact. 188:144150.

Shankaranarayan, D., Gopalakhrishnan, C., kameswaran, L. 1979. Pharmacological profile of mangostin and its derivatives. Arch Internet Pharmaco Therapie. 239: 257-269.

Suksamrarn, S., Suwannapoch, N., Pakhodee, W., Thanuhiranlert, J., Ratnanukul, P., Chimnoi, N and Suksamrarn, A. 2003. Antimycro-bacterial Activity of Prenylatedxanthones From the Fruits of Garcinia mangostana. Chem Pharm Bull (Tokyo). 51(7):857-859.
Syamsudin., Farida., Widowati, D., Faizatun. 2008. Profil Distribusi dan Eliminasi Senyawa $\alpha$ Mangostin setelah Pemberian Oral pada Tikus. Jurnal Sains dan Teknologi Farmasi. 13(2):53-58 